\title{
Effect of Performance Assessment and Compensation on Lecturer and Employee Productivity in The Faculty of Education and Science North Sumatera Islamic University
}

\author{
Melinda Siregar \\ Faculty of Economy, Universitas Prima Indonesia, Medan, 20118, Indonesia \\ melindasiregar@unprimdn.ac.id \\ Whatsapp Number [ +6281396866660]
}

How to Cite : Siregar, M. (2019). Effect of Performance Assessment and Compensation on Lecturer and Employee Productivity in The Faculty of Education and Science North Sumatera Islamic University. International Journal for Educational and Vocational Studies, 1 (5), 495-502

\section{ARTICLE HISTORY}

Received: 13 July 2019

Revised: 26 July 2019

Accepted: 28 August 2019

\section{KEYWORDS}

Performance Assessment ; Compensation;

Lecturer productivity;

Employee;

\begin{abstract}
Performance Appraisal is an effort to identify, measure (assess) and manage (management) to determine decisions about success or failure in carrying out work carried out by workers with work standards set by the company. Compensation for organizations / companies means rewards / rewards to workers who have contributed in realizing their goals, through activities called work. Total productivity is nothing but the ratio of what is produced (out put) to all what is used (in put) to obtain these results. FKIP-UISU Medan is part of one of the faculties at the Islamic University of North Sumatra Medan and its address at Jalan Puri Number 18 Simpang Jalan Alloy Tenaga Medan. The problem formulation is "How big is the effect of performance appraisal and compensation on the productivity of lecturers and staff at the Teaching and Education Faculty of the Islamic University of North Sumatra". The purpose of this study was to determine the FKIP-UISU lecturer and staff assessment of performance appraisals, compensation provided, level of productivity. The results of the study using the formula of multiple correlation between variables $x 1$ (performance appraisal) and $x 2$ (compensation) together with variable y (productivity of lecturers and staff) that is 0.826 which means it has a positive relationship because $r$ count is greater than rtable $(0.826>0.361)$. Based on the table, it is known that $=0.826$ is at the coefficient interval $0.80-1,000$, then the relationship of variable $\mathrm{x} 1$ (performance appraisal) with variable $\mathrm{x} 2$ (compensation) which is jointly correlated with variable y (lecturer and employee productivity) is included in the category very strong relationship. Based on the calculation of the value of Fcount $=28.890$ this value is then consulted with Ftable with an error rate of $5 \%$ based on the numerator $\mathrm{dk}=\mathrm{k}(2)$ and the denominator $\mathrm{dk}=\mathrm{n}-\mathrm{k}-1$ (27), then Ftable $=3.35$ is obtained. These results indicate that Fcount is greater than Ftable, 28.890> 3.35. Because the price of Fcount is far greater than the price of Fable, the proposed Zero Hypothesis $(\mathrm{HO})$ is rejected and the Alternative Hypothesis $(\mathrm{Ha})$ is accepted. According to the results of these calculations it can be concluded that the productivity of lecturers and staff at the Teaching and Education Faculty of the Islamic University of North Sumatra, Medan is influenced by performance evaluation and compensation variables of $68.15 \%$, while $31.85 \%$ is influenced by other variables.
\end{abstract}

This is an open access article under the CC-BY-SA license.

\section{INTRODUCTION}

Everyone wants their life's needs to be fulfilled in a moral and material form. To achieve this humanity must worship and work hard. By working hard, and accompanied by sincere and sincere intentions and honesty will get compensation. Receiving appropriate compensation from the above can improve employee or employee welfare. An organization or company in providing compensation to employees or employees based on the results of performance appraisals. A planned system is needed to get an appropriate performance evaluation so that the compen- sation given by the company to employees or employees is effective and efficient. If the compensation received matches the employee's performance or the employee will get satisfaction at work, because his performance is valued by the company. The company also receives great benefits, because satisfaction is important in increasing employee or employee productivity, so that company goals can be achieved. Based on the description above it can be assumed that performance evaluation is very important as a basis for compensation in order to increase employee productivity in a company, particularly the Teaching and Education 
Faculty of the North Sumatra Islamic University (FKIP-UISU) Medan, so the authors are interested in conducting further research by choosing the title: "The Effect of Performance Appraisal and Compensation on the Productivity of Lecturers and Staff at the Teaching and Education Faculty of the Islamic University of North Sumatra."

\section{METHODS}

\subsection{Research Location, Research Object, and Research Time}

\subsubsection{Research Location}

The location of the study was conducted at the Teaching and Education Faculty of the Islamic University of North Sumatra, Medan, which is located at Campus I of UISU, Jalan SM Raja Teladan, Medan.

\subsubsection{Research Objects}

The object of research is the performance appraisal variable and compensation as well as its effect on productivity.

\subsubsection{Research Time}

This research is planned by the author starting from April to July 2019.

\subsection{Population and Sample}

\subsubsection{Population}

According to Sugiyono (2005:72) the population is a generalization area consisting of: objects / subjects that have certain quantias and characteristics determined by researchers to be studied and then conclusions drawn. As for the population in this study were all Employees (Lecturers and Staff) in the Teaching and Education Faculty of the Islamic University of North Sumatra, Medan, amounting to 60 people.

\subsubsection{Samples}

Sugiyono (2005: 73) states the sample is part of the number of characteristics possessed by the population. If the population is large, and researchers may not study everything in the population, for example due to limited funds, manpower and time, then researchers can use samples taken from that population. Istijanto (2005: 119) states that the number of samples drawn from the population often confuses researchers, because there are no standard guidelines that can be applied to all research situations. However, what needs to be considered is the level of population homogeneity. The more homogeneous the population, the number of samples used can be reduced, whereas for populations that are increasingly heterogeneous, the number of samples needed is increasingly large, so that differences or variations that can be covered entirely.

\subsection{Data Collection Techniques}

To obtain the data and information needed, the following data collection techniques are used:

\section{Interview}

Namely communicating directly (face to face) to the parties involved in this research.

\section{Questionnaire}

That is compiling a list of questions that are shown to respondents.

\section{Document Study}

Namely data obtained from company archives relating to the research title.

\subsection{Data Analysis Techniques}

\subsubsection{Descriptive Analysis Method}

That is an analysis process that begins by collecting data and then compiling by reporting it, analyzing and interpreting it so that a clear picture of the facts under study is obtained.

\subsubsection{Quantitative Analysis Method}

Namely testing and analyzing data by calculating the numbers and then drawing conclusions from the test, with the following formula:

a. Product Moment Correlation Test (Partial Test) to find the relationship between performance appraisal $(\mathrm{x} 1)$ to productivity (y), then the product moment formula from Karl Pearson (1857-1936) is quoted from Sugiyono (2005: 182)

b. Hypothesis test partially or t test

c. Double Correlation (Simultaneous Test) Multiple correlation is used to find the simultaneous relationship between performance appraisal and compensation for productivity in the Teaching and Education Faculty of the Sumatara Islamic University, Medan by using the multiple correlation formula

\section{RESULTS AND DISCUSSION}

Here are the data from the field observations:

a. Data on the results of a questionnaire trial of 30 respondents consisting of employees and lecturers

b. Data on result of 3 aspects from 30 respondents 

Table 1. F test Table Questionnaire Calculation of 30 Respondents :

\begin{tabular}{|c|c|c|c|c|c|c|c|c|c|}
\hline No. Res. & $\mathrm{x}_{1}$ & $\mathrm{x}_{2}$ & $\mathrm{y}$ & $\mathrm{x}_{1}{ }^{2}$ & $\mathrm{x}_{2}{ }^{2}$ & $\mathrm{y}^{2}$ & $\mathrm{x}_{1} \mathrm{y}$ & $\mathrm{x}_{2} \mathrm{y}$ & $\mathrm{x}_{1} \mathrm{x}_{2}$ \\
\hline 1 & 43 & 42 & 40 & 1849 & 1764 & 1600 & 1720 & 1680 & 1806 \\
\hline 2 & 42 & 40 & 40 & 1764 & 1600 & 1600 & 1680 & 1600 & 1680 \\
\hline 3 & 46 & 50 & 50 & 2116 & 2500 & 2500 & 2300 & 2500 & 2300 \\
\hline 4 & 40 & 45 & 42 & 1600 & 2025 & 1764 & 1680 & 1890 & 1800 \\
\hline 5 & 41 & 40 & 40 & 1681 & 1600 & 1600 & 1640 & 1600 & 1640 \\
\hline 6 & 39 & 46 & 42 & 1521 & 2116 & 1764 & 1638 & 1932 & 1794 \\
\hline 7 & 43 & 43 & 41 & 1849 & 1849 & 1681 & 1763 & 1763 & 1849 \\
\hline 8 & 45 & 33 & 45 & 2025 & 1089 & 2025 & 2025 & 1485 & 1485 \\
\hline 9 & 42 & 42 & 43 & 1764 & 1764 & 1849 & 1806 & 1806 & 1764 \\
\hline 10 & 43 & 42 & 38 & 1849 & 1764 & 1444 & 1634 & 1596 & 1806 \\
\hline 11 & 43 & 46 & 48 & 1849 & 2116 & 2304 & 2064 & 2208 & 1978 \\
\hline 12 & 44 & 47 & 43 & 1936 & 2209 & 1849 & 1892 & 2021 & 2068 \\
\hline 13 & 41 & 44 & 40 & 1681 & 1936 & 1600 & 1640 & 1760 & 1804 \\
\hline 14 & 39 & 41 & 40 & 1521 & 1681 & 1600 & 1560 & 1640 & 1599 \\
\hline 15 & 44 & 40 & 39 & 1936 & 1600 & 1521 & 1716 & 1560 & 1760 \\
\hline 16 & 41 & 40 & 38 & 1681 & 1600 & 1444 & 1558 & 1520 & 1640 \\
\hline 17 & 49 & 46 & 46 & 2401 & 2116 & 2116 & 2254 & 2116 & 2254 \\
\hline 18 & 41 & 41 & 45 & 1681 & 1681 & 2025 & 1845 & 1845 & 1681 \\
\hline 19 & 42 & 43 & 41 & 1764 & 1849 & 1681 & 1722 & 1763 & 1806 \\
\hline 20 & 44 & 45 & 41 & 1936 & 2025 & 1681 & 1804 & 1845 & 1980 \\
\hline 21 & 41 & 43 & 48 & 1681 & 1849 & 2304 & 1968 & 2064 & 1763 \\
\hline 22 & 46 & 47 & 45 & 2116 & 2209 & 2025 & 2070 & 2115 & 2162 \\
\hline 23 & 38 & 40 & 42 & 1444 & 1600 & 1764 & 1596 & 1680 & 1520 \\
\hline 24 & 42 & 42 & 43 & 1764 & 1764 & 1849 & 1806 & 1806 & 1764 \\
\hline 25 & 41 & 44 & 45 & 1681 & 1936 & 2025 & 1845 & 1980 & 1804 \\
\hline 26 & 41 & 44 & 45 & 1681 & 1936 & 2025 & 1845 & 1980 & 1804 \\
\hline 27 & 43 & 39 & 39 & 1849 & 1521 & 1521 & 1677 & 1521 & 1677 \\
\hline 28 & 42 & 44 & 41 & 1764 & 1936 & 1681 & 1722 & 1804 & 1848 \\
\hline 29 & 35 & 43 & 42 & 1225 & 1849 & 1764 & 1470 & 1806 & 1505 \\
\hline 30 & 31 & 44 & 41 & 961 & 1936 & 1681 & 1271 & 1804 & 1364 \\
\hline$\Sigma$ & 1252 & 1286 & 1273 & 52570 & 55420 & 54287 & 53211 & 54690 & 53705 \\
\hline
\end{tabular}


Table 2. Point calculation table Performance Evaluation Aspects of 30 respondents

\begin{tabular}{|c|c|c|c|c|c|c|c|c|c|c|}
\hline \multirow{2}{*}{ No. Responden } & \multicolumn{10}{|c|}{ Performance Evaluation } \\
\hline & 1 & 2 & 3 & 4 & 5 & 6 & 7 & 8 & 9 & 10 \\
\hline 1 & SS & SS & SS & $S$ & $S$ & $S$ & STS & $S$ & TS & KS \\
\hline 2 & SS & SS & $S$ & $S$ & $S$ & KS & STS & SS & KS & $S$ \\
\hline 3 & SS & SS & SS & SS & SS & SS & STS & SS & SS & SS \\
\hline 4 & SS & S & S & $S$ & S & $S$ & TS & $S$ & TS & KS \\
\hline 5 & S & SS & S & $S$ & S & $S$ & KS & $S$ & STS & $S$ \\
\hline 6 & SS & SS & S & S & S & KS & KS & SS & S & S \\
\hline 7 & SS & SS & $S$ & SS & $S$ & $S$ & STS & $S$ & KS & $S$ \\
\hline 8 & SS & SS & SS & SS & $S$ & SS & STS & $S$ & KS & $S$ \\
\hline 9 & SS & SS & $S$ & $S$ & SS & $S$ & $\mathrm{KS}$ & $S$ & TS & S \\
\hline 10 & SS & SS & SS & SS & $S$ & $S$ & STS & $S$ & KS & KS \\
\hline 11 & SS & SS & SS & SS & SS & SS & TS & $S$ & KS & TS \\
\hline 12 & SS & SS & $S$ & SS & $S$ & SS & TS & $S$ & TS & $S$ \\
\hline 13 & SS & SS & $S$ & SS & SS & KS & KS & SS & KS & KS \\
\hline 14 & SS & SS & $S$ & $S$ & $S$ & KS & KS & $S$ & KS & $S$ \\
\hline 15 & $S$ & SS & SS & SS & SS & $S$ & TS & $S$ & TS & $S$ \\
\hline 16 & SS & SS & $S$ & $S$ & $S$ & $S$ & TS & $S$ & KS & $S$ \\
\hline 17 & SS & SS & SS & SS & SS & SS & STS & $S$ & STS & SS \\
\hline 18 & SS & SS & SS & SS & $S$ & $S$ & $\mathrm{KS}$ & $S$ & $S$ & S \\
\hline 19 & $S$ & SS & $S$ & SS & SS & $S$ & TS & $S$ & KS & $S$ \\
\hline 20 & SS & SS & SS & SS & SS & SS & TS & SS & KS & TS \\
\hline 21 & SS & SS & $S$ & S & SS & SS & $\mathrm{KS}$ & SS & $S$ & $\mathrm{KS}$ \\
\hline 22 & SS & SS & $S$ & $S$ & SS & SS & STS & $S$ & TS & SS \\
\hline 23 & SS & $S$ & $S$ & $S$ & $S$ & KS & TS & $S$ & TS & TS \\
\hline 24 & SS & SS & $S$ & SS & SS & $S$ & KS & $S$ & TS & $\mathrm{KS}$ \\
\hline 25 & $S$ & $S$ & $S$ & $S$ & SS & $S$ & TS & $S$ & TS & $S$ \\
\hline 26 & $S$ & $S$ & $S$ & $S$ & SS & $S$ & TS & $S$ & TS & $S$ \\
\hline 27 & $S$ & $S$ & $S$ & SS & SS & $S$ & STS & $S$ & TS & $S$ \\
\hline 28 & $S$ & SS & $S$ & SS & SS & SS & KS & $S$ & STS & TS \\
\hline 29 & STS & SS & SS & $S$ & SS & $S$ & SS & $S$ & SS & SS \\
\hline 30 & STS & SS & $S$ & SS & $S$ & TS & $\mathrm{KS}$ & TS & SS & $S$ \\
\hline
\end{tabular}

Table 3. Point calculation table Compensation Aspects of 30 respondents

\begin{tabular}{|c|c|c|c|c|c|c|c|c|c|c|}
\hline \multirow{2}{*}{$\begin{array}{c}\text { No. } \\
\text { Responden }\end{array}$} & \multicolumn{10}{|c|}{ Compensation } \\
\cline { 2 - 18 } & 1 & 2 & 3 & 4 & 5 & 6 & 7 & 8 & 9 & 10 \\
\hline 1 & S & S & S & S & S & S & SS & SS & S & S \\
\hline
\end{tabular}




\begin{tabular}{|c|c|c|c|c|c|c|c|c|c|c|}
\hline 2 & $S$ & $S$ & $S$ & $S$ & TS & $S$ & SS & SS & $S$ & $S$ \\
\hline 3 & SS & SS & SS & SS & SS & SS & SS & SS & SS & SS \\
\hline 4 & $S$ & $S$ & SS & $S$ & SS & $S$ & SS & SS & $S$ & SS \\
\hline 5 & $S$ & $S$ & SS & $S$ & $S$ & STS & SS & SS & $S$ & $S$ \\
\hline 6 & SS & SS & SS & KS & $S$ & $S$ & SS & SS & SS & SS \\
\hline 7 & $S$ & $S$ & SS & $S$ & KS & SS & SS & SS & $S$ & $S$ \\
\hline 8 & $S$ & $S$ & KS & KS & KS & $S$ & KS & KS & KS & KS \\
\hline 9 & $S$ & $S$ & $S$ & $S$ & SS & $S$ & $S$ & $S$ & SS & $S$ \\
\hline 10 & $S$ & $S$ & $S$ & $S$ & $S$ & $S$ & $S$ & SS & SS & $S$ \\
\hline 11 & $S$ & SS & $S$ & SS & KS & SS & SS & SS & SS & SS \\
\hline 12 & SS & $S$ & SS & SS & SS & $S$ & SS & SS & SS & $S$ \\
\hline 13 & SS & $S$ & SS & SS & TS & SS & SS & SS & $S$ & $S$ \\
\hline 14 & $S$ & $S$ & $S$ & $S$ & KS & $S$ & SS & SS & $S$ & $S$ \\
\hline 15 & $S$ & $S$ & $S$ & $S$ & $S$ & $S$ & $S$ & $S$ & $S$ & $S$ \\
\hline 16 & $S$ & $S$ & $S$ & $S$ & $S$ & $S$ & $S$ & $S$ & $S$ & $S$ \\
\hline 17 & SS & SS & SS & SS & STS & SS & SS & SS & SS & SS \\
\hline 18 & $S$ & $S$ & KS & $S$ & $S$ & $S$ & SS & SS & KS & SS \\
\hline 19 & SS & KS & $S$ & SS & $S$ & $S$ & SS & SS & $S$ & $S$ \\
\hline 20 & SS & $S$ & KS & SS & KS & SS & SS & SS & SS & SS \\
\hline 21 & KS & $S$ & $S$ & KS & $S$ & SS & SS & SS & SS & SS \\
\hline 22 & SS & $S$ & SS & SS & KS & SS & SS & SS & SS & SS \\
\hline 23 & $S$ & $S$ & $S$ & $S$ & $S$ & $S$ & $S$ & $S$ & $S$ & $S$ \\
\hline 24 & $S$ & $S$ & $S$ & $S$ & KS & $S$ & SS & SS & $S$ & SS \\
\hline 25 & $S$ & $S$ & SS & $S$ & $S$ & $S$ & SS & SS & $S$ & SS \\
\hline 26 & $S$ & $S$ & SS & $S$ & $S$ & $S$ & SS & SS & $S$ & SS \\
\hline 27 & $S$ & KS & KS & KS & $S$ & SS & $S$ & SS & $S$ & $S$ \\
\hline 28 & KS & $S$ & $S$ & SS & SS & $S$ & SS & SS & $S$ & SS \\
\hline 29 & $S$ & $S$ & SS & $S$ & SS & $S$ & $S$ & SS & $S$ & $S$ \\
\hline 30 & $S$ & $S$ & SS & $S$ & SS & $S$ & SS & SS & $S$ & $S$ \\
\hline
\end{tabular}

Table 4. Point calculation table Productivity Aspects of 30 respondent

\begin{tabular}{|c|c|c|c|c|c|c|c|c|c|c|}
\hline \multirow{2}{*}{$\begin{array}{c}\text { No. } \\
\text { Responden }\end{array}$} & \multicolumn{9}{|c|}{ Productivity } \\
\cline { 2 - 12 } & 1 & 2 & 3 & 4 & 5 & 6 & 7 & 8 & 9 & 10 \\
\hline 1 & S & KS & S & S & SS & S & S & S & S & S \\
\hline 2 & S & TS & KS & S & SS & S & SS & S & S & SS \\
\hline 3 & SS & SS & SS & SS & SS & SS & SS & SS & SS & SS \\
\hline 4 & SS & KS & S & SS & S & S & S & S & SS & S \\
\hline 5 & SS & KS & TS & S & S & S & S & S & SS & SS \\
\hline
\end{tabular}




\begin{tabular}{|c|c|c|c|c|c|c|c|c|c|c|}
\hline 6 & SS & KS & KS & $S$ & SS & $S$ & $S$ & SS & $S$ & SS \\
\hline 7 & SS & STS & SS & $S$ & $S$ & $S$ & SS & $S$ & SS & $S$ \\
\hline 8 & SS & STS & SS & SS & SS & SS & SS & SS & $S$ & SS \\
\hline 9 & $S$ & SS & KS & SS & $S$ & SS & $S$ & $S$ & $S$ & SS \\
\hline 10 & $S$ & TS & $S$ & $S$ & $S$ & $S$ & $S$ & $S$ & $S$ & $S$ \\
\hline 11 & SS & KS & SS & SS & SS & SS & SS & SS & SS & SS \\
\hline 12 & $S$ & TS & SS & SS & SS & SS & SS & $S$ & $S$ & $S$ \\
\hline 13 & $S$ & TS & KS & $S$ & $S$ & $S$ & SS & $S$ & SS & SS \\
\hline 14 & $S$ & KS & $S$ & $S$ & $S$ & $S$ & SS & $S$ & $S$ & $S$ \\
\hline 15 & $S$ & KS & $S$ & $S$ & $S$ & $S$ & $S$ & $S$ & $S$ & $S$ \\
\hline 16 & $S$ & TS & $S$ & $S$ & $S$ & $S$ & $S$ & $S$ & $S$ & $S$ \\
\hline 17 & SS & STS & SS & SS & SS & SS & SS & SS & SS & SS \\
\hline 18 & SS & KS & SS & SS & SS & SS & $S$ & SS & $S$ & $S$ \\
\hline 19 & $S$ & TS & SS & SS & $S$ & SS & SS & KS & $S$ & $S$ \\
\hline 20 & SS & TS & KS & SS & $S$ & SS & $S$ & $S$ & SS & $S$ \\
\hline 21 & SS & KS & SS & SS & SS & SS & SS & SS & SS & SS \\
\hline 22 & SS & KS & $S$ & SS & SS & SS & SS & $S$ & $S$ & SS \\
\hline 23 & $S$ & $S$ & $S$ & $S$ & SS & SS & $S$ & $S$ & $S$ & $S$ \\
\hline 24 & $S$ & TS & $S$ & SS & SS & SS & SS & SS & SS & KS \\
\hline 25 & SS & TS & $S$ & $S$ & SS & SS & SS & SS & SS & SS \\
\hline 26 & SS & TS & $S$ & $S$ & SS & SS & SS & SS & SS & SS \\
\hline 27 & $S$ & TS & $S$ & SS & $S$ & $S$ & KS & $S$ & SS & $S$ \\
\hline 28 & SS & TS & $S$ & $S$ & SS & $S$ & S & $S$ & SS & $S$ \\
\hline 29 & SS & $S$ & TS & $S$ & $S$ & SS & SS & $S$ & $S$ & SS \\
\hline 30 & SS & $S$ & STS & $S$ & SS & $S$ & SS & SS & $S$ & $S$ \\
\hline
\end{tabular}

\section{RESPONDENTS AMOUNT ANALYSIS}

In the following bar chart graph can be seen the total accumulated amount of measurement measurements for each point in each aspect in total. on the bar graph the symbols "SS" (really like), "S" (like), "KS" (less like), "TS" (don't like), "' STS "(very dislike).

\section{a. Product Moment Correlation Test (Partial Test)}

To calculate whether the relationship between variable $\mathrm{x} 1$ (Performance Appraisal) and variable y (Productivity of Lecturers and Staff) is significant or not, it can be seen through the calculation that the result is 0.807 . The calculation results above $=0.807$ is the result of the correlation between the variable $\mathrm{x} 1$ (performance appraisal) and the variable y (lecturer and employee productivity) is positive, because the $r$ count is greater than the table $(0.807>0.361)$. To calculate whether the relationship between variable $\mathrm{x} 2$ (Compensation) and variable $\mathrm{y}$
(Productivity of Lecturers and Staff) is significant or not, it can be known through calculation and the results of 0.706 . The calculation result above $=0.706$ is the result of the correlation between the variable $\mathrm{x} 2$ (performance appraisal) and the variable y (lecturer and staff productivity) is positive, because the $r$ count is greater than the table $(0.706>0.361)$. The calculation result above $=0.725$ is the result of the correlation between the variable $\mathrm{x} 1$ (performance evaluation) and the variable $\mathrm{x} 2$ (compensation) is positive, because the $\mathrm{r}$ count is greater than the rtable $(0.725>0.361)$

\section{b. Hypothesis of Partially Test or t-Test}

To find out the value of this coefficient is significant or can not be calculated and the results of the above calculation = 7.227 , with an error level of $5 \%$ and $\mathrm{dk}=28$ obtained price table $=2.048$, then the correlation coefficient is significant, because tcount is greater than the table $(7.227>2.048)$. The calculation results above $=5.268$, with an error level of 
$5 \%$ and $\mathrm{dk}=28$ obtained the value of ttable $=2.048$, then the correlation coefficient is significant, because tcount is greater than ttable $(5.268>2.048)$. The calculation results above $=5.578$, with an error level of $5 \%$ and $\mathrm{dk}=28$ obtained the value of $\mathrm{t}$ table $=2.048$, then the correlation coefficient is significant, because tcount is greater than the table $(5.578>2.048)$.

\section{c. Double Correlation (Simultaneous Test)}

Then to find out the correlation between variables $\mathrm{x} 1$ (Performance Assessment) and x2 (Compensation) on the Productivity of Lecturers and Staff (y) in FKIP-UISU, whether significant or not, can be calculated using multiple correlation analysis the following results are obtained. The results of these calculations are the values obtained from the calculation of the correlation between the variables $\mathrm{x} 1$ (performance appraisal) and $\mathrm{x} 2$ (compensation) together with the variable y (lecturer and employee productivity) which is 0.826 which means it has a positive relationship because the $r$ count is greater than the rtable ( 0.826> 0.361). Based on the table, it is known that $=0.826$ is at the coefficient interval $0.80-1,000$, then the relationship of variable $\mathrm{x} 1$ (performance appraisal) with variable $\mathrm{x} 2$ (compensation) which is jointly correlated with variable $y$ (lecturer and employee productivity) is included in the category very strong relationship.

\section{d. Simultaneous hypothesis test or F-test}

To see whether the coefficient can be generalized, the significance must be tested through calculations and the value of Fcalculate $=28.890$ this value is then consulted with Ftable with a $5 \%$ error level based on the numerator $\mathrm{dk}=\mathrm{k}(2)$ and $\mathrm{dk}$ the denominator $=\mathrm{nk}-1$ (27), then obtained Ftable $=3.35$. These results indicate that Fcount is greater than Ftable, 28.890> 3.35. Because the price of Fcount is far greater than the price of Fable, the proposed Zero Hypothesis (H0) is rejected and the Alternative Hypothesis (Ha) is accepted.

\section{e. Determinant Test (D)}

Furthermore, to see which variable is the most influential between performance appraisal and compensation for the productivity of lecturers and staff at the Teaching and Education Faculty of the Islamic University of North Sumatra, Medan, a determinant test (D) was conducted with the following results:

$\mathrm{D}=\mathrm{x} 100 \%$

$\mathrm{D}=(0.826) 2 \times 100 \%$

$\mathrm{D}=0.6815 \times 100 \%$

$\mathrm{D}=68.15 \%$

From the results of these calculations it can be concluded that the productivity of lecturers and staff at the Teaching and Education Faculty of the Islamic University of North Sumatra, Medan is influenced by variables outside the contribution of this study such as leadership, communication, and Occupational Safety and Health (K3).

\section{CONCLUSION}

Based on the results of the descriptions above, the following conclusions can be drawn:

(1)Performance Appraisal is an effort to identify, measure (assess) and manage (management) to determine decisions about success or failure in carrying out work carried out by workers with work standards set by the company.

(2) Compensation for the organization/company means appreciation/reward to workers who have contributed in realizing their goals, through activities called work.

(3) Total productivity is nothing but the ratio of what is produced (output) to all what is used (input) to obtain these results.

(4) In accordance with the analysis and evaluation obtained, that the performance appraisal has a significant influence or role on the productivity of lecturers and staff at the Teaching and Education Faculty of the North Sumatra Islamic University in Medan which can be seen from the calculated value of rtable $(0.807>$ 0.361). Where the effect is positive. Then compensation has a significant role or influence on the productivity of lecturers and staff at the Teaching and Education Faculty of the Islamic University of North Sumatra, Medan, which can be seen from the calculated value of rtable $(0.706>0.361)$. and has a positive influence. Whereas performance appraisal has influence or a significant role in compensation in the Teaching and Education Faculty of the Islamic University of North Sumatra, Medan, which can be seen from the size of the rtable $(0.725>0.361)$.

(5) Based on the calculation of the value of Fcount $=28.890$ this value is then consulted with Ftable with a 5\% error level based on the numerator $\mathrm{dk}=\mathrm{k}$ (2) and the denominator $\mathrm{dk}=\mathrm{n}-\mathrm{k}-1$ (27), then Ftable $=3.35$ is obtained. These results indicate that Fcount is greater than Ftable, 28.890> 3.35. Because the price of Fcount is far greater than the price of Fable, the proposed Zero Hypothesis (H0) is rejected and the Alternative Hypothesis (Ha) is accepted.

(6) According to the results of these calculations it can be concluded that the productivity of lecturers and staff at the Teaching and Education Faculty of the Islamic University of North Sumatra, Medan is influenced by the performance evaluation and compensation variables of $68.15 \%$, while $31.85 \%$ is influenced by other variables.

\section{REFERENCES}

Anoraga, P. (2005). Psikologi Kerja, Cet. III, Rineka Cipta, Jakarta.

Arikunto, S. (1991). Prosedur Penelitian: Suatu Pendekatan Praktik, Rineka Cipta, Jakarta.

FKIP-UISU, (2006). Buku Pedoman Tahun Akademi 2006/2007, Medan. 
Istijanto, (2005). Riset Sumber Daya Manusia: Cara Praktis Mendeteksi Dimensi-Dimensi Kerja Karyawan, PT. Gramedia Pustaka Utama, Jakarta.

Nawawi, H. (1991). Metode Penelitian Bidang Sosial, UGM Press, Yogyakarta.

Nawawi, H. (2005). MSDM Untuk Bisnis Yang Kompetitif, Cet. 6, UGM Press, Yogyakarta

Rivai, V. (2005). Manajemen Sumber Daya Manusia Untuk Perusahaan: Dari Teori ke Praktik, PT Raja Grafindo Persada, Jakarta.

Rivai, V. (2005). Performance Appraisal: Sistem yang Tepat untuk Menilai Kinerja Karyawan dan Meningkatkan Daya Saing Perusahaan, Rajawali Pers, Jakarta.

Siagian, S., P. (2002). Kiat Meningkatkan Produktivitas Kerja, Rineka Cipta, Jakarta.

Siagian, S., P. (2005). Manajemen Sumber Daya Manunsia, Cet. 12, Bumi Aksara, Jakarta.

Sugiyono, (2005). Metodologi Penelitian Bisnis, CV. Afabeta, Jakarta.

Suryabrata, (1991). Metodologi Penelitian, CV. Rajawali, Jakarta.

Syarif, R. (1991). Produktivitas: Seri Manajemen dan Produktivitas, Angkasa, Bandung 